\title{
New Demands and Expectations in the City Tourism and Does the City of Niš Welcome Them
}

Milica Began*, Marija Stefanović**

Received: March 2014 | Accepted: November 2014

\begin{abstract}
Following tourist offers, one must notice the appearance of some new trends in the field city tours. Understanding the fact that this geographical area (South Serbia) is economically less developed then the area of Middle and North Serbia, one can expect the lack of tourist offer that could satisfy the needs of a modern tourist. But knowing that Niš stands on a very important historical and geographical crossroads and represents the religious, cultural, political, sports etc. junction one must expect a modern tourist offer that will satisfy today's tourists. This paper will show that Niš and some of the people working in tourism branch recognized these new tourists' expectations and are the pioneers now in this area, trying to offer a different tourist product to tourists coming to this city. Regardless to the subjective and objective problems they face on the road to a genuine thematic tourist product, they tend to offer a brand new product that will satisfy foreign tourists and teach domestic tourist about the new trends in satisfying tourist needs.
\end{abstract}

Key words: city tour, wine tourism, extreme tourism, new offers

\section{Introduction}

Generally, we can define a need as the inner tension or a kind of dissatisfaction a person needs to remove. The needs are constant and can't be ignored. One of their characteristics is that they tend to change. We also know that a need can cause the appearance or disappearance of another need. The needs are usually defined as primary and secondary: (Dobre, 2005)

- Primary needs are: the need for air, water, food... They are called "primary" because we tend to satisfy them first,

- Secondary needs are the acquired needs we get through time. The need for travel and leisure is a secondary need. Although, in the modern era it is noted that this need tends to turn into a primary need in a way.

* University of Novi Sad, Faculty of Sciences, Department of Geography, Tourism and Hotel Management, Corresponding author: voyageouse@gmail.com

** University of Niš, Faculty of Economics 
The needs are hard to measure, because we reduce them to wind chill (Jovičić, I992). The need for tourism and leisure in its first phase is individual, expressed as the need for vacation, rest, getting to know the new things that are away from our resident place (Jovičić, I992). The need for tourism and leisure is a need for: recreation, rest, cultural satisfaction, getting closer to different people all around the world, getting to know different locations, the need for fun and leisure etc. The thing about the need for tourism and leisure is that once you try to satisfy it: you get "hungrier" for it. The need for tourism and leisure is impossible to satisfy (Dobre, 2005). It makes you want more. Also, it makes you want something different. For example: once a person satisfies the need for the Sun and sea, he or she will start to feel a need for a mountain and snow... This need allows us to create all kinds of tourist offers and combinations where we can offer the potential tourists a satisfaction of their needs and also to animate them and create the new needs that could be satisfied in the future.

\section{The tendency of a new tourist need}

Having in mind that mass production, mass construction, mass tourism are less and less sustainable and therefore attractive than they used to be, noticing that travel agencies and tour operators follow the trends and costumers wishes and needs, one must confirm that tourism today experienced major changes. The new tourist is educated and tired. The new tourist wants nature, new and unseen landscapes, he/she needs an active vacation, he/she wants to eat and drink local.

Areas and attractions that were able to satisfy tourists' needs in the beginning, now has to have extraordinary features in order to satisfy heterogeneous tourist demands (Štetić, et al 20I3). According to the new needs and trends, we discovered brand new destinations, untouched nature, new ways of spending leisure time. Mass tourism, still present on summer destinations on the Mediterranean, is slowly becoming suppressed by the new era tourism. The new era tourist is interested in:

- Landscapes, such as deserts, forests, virgin forests, waterfalls, canyons etc.

- Activities connected to the landscapes: watching, taking photographs, climbing, hiking, canoeing etc.

- Short visits to various events: artistic, sports, festivals etc.

- Visits and stays in old settlements,

- Learning foreign languages in the countries the language is originally spoken,

- Hunting and fishing,

- Jeep safari,

- Cycling tours,

- Food, drinks and wine,

- Specialized hotels: casinos, wellness, thematic hotels etc.

- Big cities nightlife with the visits to the most prestigious night clubs.

Tourists with those special interests show tendency for authentic and real experiences that offer them identification with locals without disturbing their daily routine (Genov, 2008). These are some of the interests of the new era tourists, who wish to change their everyday life and satisfy their needs, even the most lascivious ones. Following those needs, some travel agencies in Serbia recognized Serbia as an interesting destination that can use natural resources to satisfy many of the needs of this new era tourist. Tourist organization 
of Serbia (TOS) recognized one of the Serbia's advantages and created the marketing campaign called SoulFood. The SoulFood project is designed to celebrate organic, tasteful and high quality food grown in Serbia, combined with our well known hospitality, and the saying: "Come in, eat something!"

\section{The definition of a tourist product}

Connected to the tourist need, people created a specific product - tourist product. A product designed to satisfy the need for tourism and leisure. The need for tourism and leisure can be satisfied with tourist goods and services of economic significance (Stefanović, Azemović, 2OII). A tourist product is a specific product, designed to satisfy the specific tourist need and as such is sold on the market for a certain price. Classic definition of a tourist product is a set of base and complementary services combined (Štetić et al 2OI3). The last decade changed this definition, making a tourist product a wider term. In tourism, product can be a service, or a celebrity (famous singer or a sports player), places (mount Kopaonik, Hawaii...), events or manifestations (EXIT, BEMUS, NIMUS...), organizations and associations (Red Cross, Jazas...), ideas (how to reduce fuel consumption or to increase train safety...) (Veljković, 2009). Today we can freely say that everything that attracts tourists' attention is a tourist product.

\section{City tour tourist product in Niš}

Author Milenković S. (I999) noted that tourism growth trends rise to new philosophy of tourism treatment. He accurately predicted that tourism will stay one of the most perspective industries ox XXI century. Following trends, people working in tourism industry in Niš started creating new tourist products. Truth to be tell, these trends aren't new in world tourism, but anyway many people are turning to these new trends.

The classic city tour product in Niš includes a classic City tour that includes visits to Čegar monument, Ćele-kula (Scull tower), Mediana archaeological site, Niška banja, the Fortress and the Concentration camp. The average duration of this tour is 3.5 to 4 hours. This tour includes a detailed history of Niš, a hop on - hop off, visit to the museums, local tour guide's interpretation of the sites. For the guide: this tour is very complex and demanding, with lots of historical information, facts and figures. For the group: this tour is also demanding, it lasts for a long time, it gives them lot of information, with no brake. For the past few years, we noticed the significant change in the tourists' affiliations. The only groups still interested in the classical City tour are elementary school students (children under I5), that come to Niš on educational field trips organized by schools. Other types of the tourists aren't interested in the classic City tour any more.

The new trends show that in general: tourists are very educated and they roughly know where they came and what do they want. But the first thing they want is: to experience something totally different. The new age tourists want to experience local food, friendships with local people, local drinks, they want to go and see and feel the nature, they want to rise up the adrenaline. Now, Niš offers a variety of different city tours that include many local experiences that make the tourists satisfied and want to come to Niš one more time. 
Table 1. Total annual visits to the sites managed by the National Museum of Niš (Source: National Museum of Niš)

\begin{tabular}{|l|r|r|r|r|}
\hline & \multicolumn{1}{|c|}{2010} & \multicolumn{1}{c|}{2011} & \multicolumn{1}{c|}{2012} & \multicolumn{1}{c|}{2013} \\
\hline Scull tower & 38707 & 29252 & N/A & 26473 \\
\hline Mediana & 13500 & 19500 & N/A & 7255 \\
\hline Concentration Camp & 9471 & 6710 & N/A & 8342 \\
\hline Archaeological Hall & 4526 & 1100 & N/A & 8946 \\
\hline
\end{tabular}

Analyzing the visits to the National Museum of Nišl we can see a solid visit to the sites managed by the Museum. Due to the untimely driven documentation, the information from the year 2OI2 is not available, and the information from 2013 is from January till the end of October 2OI3. According to the organization of the celebration of the Edict of Milan in Niš, we expected Mediana archaeological site to be the most visited one, but it was closed until June, and it had maximum visits of 279I people in September (Source: National Muesum of Niš). In contrast to these data, the attendance to a thematic exhibition surprised: "Constantine the Great and the Edict of Milan 3I3-2OI3" was open from September 2Oth until October 3Ist in the Tobacco Industry Grand gallery. For this relatively short period of time, a total of 7000 people visited the exhibition. This was noted as the most successful exhibitions the Museum ever organized. There was also one more thematic exhibition in the Synagogue gallery: "Christianity through centuries", from January until May 2OI3: it was visited by 3433 people. According to these data, provided by the National Museum of Niš, we can see that in "the year of the Edict" Niš was attractive for the tourists to visit. Having in mind the short period of the exhibition, we can confirm that the exhibition "Constantine the Great and the Edict of Milan 3I3-2OI3" had the greatest success. According to the Tourist Guides Association of Serbia branch Niš: the groups and the individuals requested thematic city tours related to Constantine the Great and the heritage connected to Roman period. Also, the guides from this Association remarked that they guided many small groups of maximum IO people.

\section{Introduction to thematic tourism}

Special interests tourism includes tourist travels motivated by special interests for some attractions and activities like: sports, nature, traditional crafts, wellness, culture, tradition, farm tourism, events, festivals, nautical etc. These types of tourism record highest growth rate, especially in Europe and USA (Unković, 2006). This is a complex phenomena market-determined through a high technology influence on a selection of tourist travels, strong market segmentation and management specifics and distributions (Štetić, et al 2OI3).

The variety of an offer in modern tourism is based on the attractive features of the resources a specific geographical area has to offer (Jovanović, 2OI3). Every area is specific in a way, and it can offer something special to attract tourists. Thematic tourism is a tourist product specific for the last decade that satisfies the new kind of tourists needs. Thematic tourism is winning the battle against mass tourism. More and more tourists are coming to the destinations individual or in small groups, organized by the preferences of the very tourists, who

1 The National Museum of Niš, Generala Milojka Lešjanina I4, Niš; www.narodnimuzejnis.rs, muzejnis@open. telekom.rs; The National Museum of Niš manages the following buildings: the Scull Tower, Mediana archaeological site, "Crveni krst" concentration camp, the Synagogue gallery, the Archaeological hall; they also organize various thematic exhibitions. 
wish not only to see the sites, but to really feel and experience the local way of life, food and many other things. According to this, we now have new kinds of tourism that can be sorted as:

I. Health and Wellness tourism

2. Spa tourism

3. City tourism

4. Rural tourism

5. Cultural tourism

6. Events and manifestations

7. Nautical tourism and cruises

8. Sports tourism

9. Educational tourism (Jovanović, 2OI3).

Thematic tourism has the characteristics of a travel with a specific cause. This kind of tourism is good for the local economy, sustainable, flexible and controlled. New age's tourists don't want to be "a part of a machinery any more", but to get the experiences alone and to feel as they belong. According to the various needs of the tourists, and the new tourism kinds - thematic kinds, created to satisfy those needs - the new types of tourism develop rapidly.

Tour guides are also faced with the new tendencies. Classic city tours are attractive only to elementary school groups of children under I5. The classic city tour of Niš coincides with the school curriculum, so during the educational field trips and excursions, the guides are requested to provide a classical sightseeing. All the other groups coming to Niš for the past 2 years had some new requests.

According to the information provided by the Tourist guide Association of Serbia - branch Niš ${ }^{2}$, the guides have noticed a signicifant change in the groups' composition and demands:

I. Composition: groups are small, up to $2 \mathrm{O}$ people. Most of the tourists are more then $4 \mathrm{O}$ years old. There are also many individual tours, with the tourists demanding a thematic tour. There are many religious groups interested in tha sacral objects in Niš and it's surroundings. Some of the guides also had a specific ethnic groups (Jews, Roma etc.) for whom they prepared specialized sightseeings. The Association noted greater interest in so called „walking tours“, not so attractive before.

2. Demands: More groups and individuals are coming with special demands, or „ordered tours“, such as: wine tour, paragliding tour, Stara Planina hiking tour, cycling tour etc.

The year 2OI3. was the year of a great celebration of signing the Edict of Milan and Niš, a birth place of Constantine the Great, was one of the host cities with the series of events concerning the celebration. The total number of tourists is still not known, but the guides noticed an interesting thing: they expected many Christian groups interested in Constantine, Roman heritage etc, instead they guided more groups with different ethnicities, interested in the heritage related to them.

Having this experience in mind, the Tourist guides Association of Serbia - branch Niš started offering a bit different tours, thematic and more attractive then the old ones. In these tours, they included the wine cellars, started cooperation with Nature Travel Office (mentioned later in this paper), different nature lovers associations, national restaurants etc.

2 Tourist guide Association of Serbia - branch Niš, Voždova 5, Niš; internal office documentation 
Having this trend in mind, a group of guiding experts, created a web site ToursByLocals. $\mathrm{com}^{3}$ by far the most successful site providing tourists and travel agencies custom made thematic tours - made by the local guides. The acceptance process is demanding and the guides working with this site are people with experience and vision. They noticed that thematic tourism is growing fast and this will be the way to earn more money then with mass tourism. Also, thematic tours, semi independent, with less tourists (small groups) are more enviromental friendly then groups in mass tourism.

ToursByLocals currently has I698 Guide-Partners in I27 different countries around the world. Those Guide-Partners have published a total of 9860 Tour "suggestions" on the site. In $2 \mathrm{OI} 2$ (I2 months) travelers booked I3.OOO tours, thus far in $2 \mathrm{OI} 3$ (January to September) I8.OOO tours have been booked by travelers, the total for the year will be more than the I8.0Oo because of the three not yet completed months of the year (stats until the end of September 2OI3).

The "typical" tour booked is a "Day" tour, 6-8 hours in duration, typically any tour that the Guide-Partner can complete in one day's work hours, in some cases it is Io hours but it would be classified as a "day tour". Typically their travelers are $55^{+}$in age and are not overly active, meaning not a significant amount of sports/adventure tours are booked. They mostly tend to focus on historic tours of the particular area in which they are booked. Their notice is that "food sells" and that the tours including wine and food tasting are the most attractive. The tours the guides in Niš had, with the cooperation of this web site included introduction and lunch in ethno restaurant.

\section{Steps towards creating high quality thematic offer in Niš}

\section{Greeting service}

Following the new trends in tourists' requests and needs, at the beginning of 2OI3 the city of Niš organized a brief course for the volunteers association „Niš Greeter Service“. The course included teaching the volunteers how to greet tourists and help them get along. Greeter Service is designed as a volunteers service, where the certified greeters greet the tourists, take them to their accommodation, help them navigate the city, and generally show the sites. Greeters take tourists to cafes and bars, experience night city life and „hang out“ with them. Their services are free for all the tourists. This is not a new trend in Europe, but the new trends comming to Niš are recognized and met by the city of Niš.

\section{Extreme tourism in Niš}

At the beginning of $2 \mathrm{OI} 3$ a historian, who had lots of experiences in climbing, hiking etc. one of the founders of the "PARK Nature" association founded a tourist office named "Nature Travel Office" ${ }^{4}$. The idea of this tourist office was to create outdoor programs, adventures that will attract people from Niš and the surroundings to try a new kind of sightseeing. This office wanted to introduce the nature surrounding Niš to the citizens, then to everyone else. On February 20I3, on International Tourist Guides Day, the Tourist Guides Association of

3 ToursByLocals.com, III2 West Pender Street, Suite 6oo, Vancouver, BC V6E 2SI, Canada

4 Nature Travel Office, Strahinjića Bana 6/2, Niš; www.naturetraveloffice.com 
Niš introduced one of the tours "When the gorge tells a story" to the wider audience. This project was very successful and helped introducing this tour and making it successful further.

The tours Nature Travel Office offers now are: $:^{5}$

- Nais adventure, a two-day speleo and track adventure,

- The Kalafat adventure, one day field trip,

- Autumn adventure on Stara planina, a two-day field trip,

- When the gorge tells a story, one day field trip.

The tours, internally called "adventures" are pretty affordable, designed for small groups, up to $2 \mathrm{O}$ people (depending on the tour). Every group is followed by the experienced sports instructors and a doctor. Also, the office, in cooperation with "PARK Nature" (alpine mountaineering and diving club from Niš), provides all the necessary equipment and transport for the tourists.

Since the opening, the office had total of 400 people attending various adventures, the average number of people per tour is IO, which gives us total of $4 \mathrm{O}$ adventures realized from January $2 \mathrm{OI} 3$ until November 2OI3. The office keeps record of the people who regularly go on adventures, and now they have around 50 people who are regular clients and often go to the adventures with this office. In general, the adventures the office sells most are one day adventures, and the bestseller is "When a gorge tells a story": trekking adventure, especially popular because of the use of the abseil technique (going down the rope). The time most suitable for those outdoor adventures are spring and autumn, because it allows creating various adventures. During the summer, the adventures popular are in the canyons, around waterfalls. Winter time demands experienced adventurers, because the adventures mean skiing, climbing frozen waterfalls etc. Nature Travel Office's general manager expects the winter season to be the lowest season, concerning these adventures demand high physical preparations.

The office is satisfied with the job done until now, and they expect to have more adventurers in the season to come. As far as the foreign tourists visit, they mention a few Australian groups coming to Niš and going on to the adventures. Their experience with foreign groups is that those groups need few days programs, full with different adventures.

\section{Vine tourism}

For the past few years, a significant demand is noticed for a tourist product that includes "wine and dine". Having in mind that Serbia wants to represent itself to a global tourist market as a country of good food and drink, we can find promotion of Serbian wine and food. Following this, in August 2010 the city of Niš organized the first annual Wine Fair. This fair was a pretty successful event and introduced wider audience the good wine Niš and the surroundings have to offer. The Wine Fair is organized once a year, usually in autumn and the "Wine and Fine" ${ }^{6}$ company's executives say that they have more audience every year. Now, the Fair is international, and for the next year this organization announces many world known wine cellars and many interesting promotions. This event, and the fact that

5 All the data is collected from www.naturetraveloffice.com; Milan Stojaković, general manager; internal office documentation

6 “Wine and Fine" Tvrđava bb, Niš 
Niš and the surroundings cherish the tradition of making good wine, can be very interesting to the modern tourists, searching authentic tastes. Organizing this fair in the time suitable for tourists - the tourist season in Niš is spring and autumn, promoting it the right way and presenting it to the wider audience can be a swell tourist product. For now, this product is not developed as it should and could be, but we think that it doesn't need much to put Niš on the "wine tourist map".

\section{Tour operators in Niš, organizing thematic tours for foreign tourists coming to Serbia}

Having lot of experience in tourism in general, after more than 30 years working in tourism, on 2005 Mr Branislav Simović decided to open an outgoing travel agency in Niš, called "Outdoor"7. This was actually a pioneer agency in extreme tourism at that time and the fact that this travel agency started bringing tourists to Niš and Serbia in the time of totally different trends in Serbia is rather interesting. Most of the partners and tourists coming to Serbia with this agency are from Israel. The agency created many tourist programs, inventive in that time, which were sold on foreign markets.

Some of the tours are:

- Bycicle tour in Serbia, IO days tour,

- Santorini-Crete, I5 days tour,

- From Dubrovnik to Belgrade, Io days tour.

Best selling tour is "From Dubrovnik to Belgrade", which includes three states: Croatia, Montenegro and Serbia. This is a mixed tour, where the means of transportation used is a boat and a bus. It includes tours of the old cities: Dubrovnik, Kotor, Budva, Sveti Stefan; natural phenomena: lakes Skadar, Crno, Biogradsko, Perućac; National Parks: Lovćen, Durmitor, river Tara canyon, Mokra Gora, Zlatibor; museums: Cetinje, Dubrovnik, Beograd; tourist attractions: Šarganska osmica railway, Drvengrad, Skadarlija. It also includes special attractions: jeep tour "Ring around Durmitor" or Tara rafting - depending on the season, and a walking tour around Biogradsko lake; sacral buildings: Morača Monastery; national folklore: Montenegro and Serbia; shopping in Belgrade.

As far as the foreign tourists using Outdoor's services, they can be divided into two groups: ${ }^{8}$

I. Classical tourists, coming for leisure and visits

2. Sport, religious, extreme and special groups of tourists

The first group is searching for the new destinations, in the world this is China, in our region this is Montenegro and Croatia. This can be defined as an effect of the sea, old Mediterranean towns etc. What is interesting also is that using the interest for our region is breaking the prejudices and creating the suitable package offers. The bestseller tour is "From Dubrovnik to Belgrade" and for the past four years 520 people experienced this tour. The maximum number of people for this tour is 20 , which means that total of 26 tours have been realized. Having in mind that the only time suitable for this tour is spring time, one can say internal office documentation

8 "Outdoor" internal office documentation 
that this is rather successful tour. This agency's experience tells us that the tourists aren't interested in one country in particular, but they wish to see and experience many attractions during their stay. Analyzing the bestseller tour, we can see that this is a thematic tour, which includes many attractions and activities.

\section{Tour operators in Niš, organizing thematic excursions for the locals}

Since 2003 a tourist agency from Niš "Nitravel" ${ }^{9}$ has been organizing daily excursions to Sofia. These tours are differentiated because of the program: the tours are called "A music day in Sofia", and are organized on Saturdays and Sundays with the sightseeing of Sofia, free time and the visit to the National Opera and Ballet. For the past ten years, this agency took its clients to many different and world known performances - operas and ballets: Werdi's Traviata, Aida, Wagner's Das Rheingold, Theodorakis' Zorba the Greek, Chaikovski's Swan Lake, Eugene Onegin and many others. Tens of thousands of people went to these excursions and visited the eminent Sofia's Opera and Ballet. These thematic excursions are current in the spring and fall and very popular.

This agency is also one of the faithful partners of the Tourist Guides Association of Serbia - branch Niš, in organizing their annual International Tourist guides Day tours. In $2 \mathrm{OI} 3$ the Association celebrated this day by organizing only thematic tours and sightseeing of Niš.

Niš Tourist Organization promotes the mixture of nature and tourism and on World Tourism Day, 27.09.2OI4, they plan to organize a thematic tour to visit Cerjanska cave, near Niš. A valuable nature monument, not yet explored and underutilized. This tour is planned to be guided by a speleo guide and followed by experienced climbers. This will be one vlauable promotion of thematic tourism in Niš, offered free for all interested citizens and guests.

\section{Conclusion}

Talking about this attractive topic, we can note that the city of Niš and some of the people working in tourism here actually recognized the new trends and started using them very early. We must use the perfect location of the town to attract tourists to come and visit Niš. The first thing is a general organization of a good and smart tourist product. The best seller should be a short city tour with a rich lunch in ethno restaurant, wine tasting and some free time. Having in mind that most of the tourists use Niš as a rest station on their way to other destinations, and business travelers, we must have such an organization that will attract tourists to come and visit. We must leave to rest the old fashion city tours, because people don't travel for many days any more and they don't have the time to go on a 4 hours sightseeing. Instead of this we can offer them diferent short tours that will include visit to the Museum and rest, food and free time. This will become the key tour in Niš city tour tourist product. People satisfying their tourist needs with nature and extreme sports must be attracted by having the best information about a beautiful surroundings and historical events that occured here. About the natural possibilities for performing different outdoor extreme sports. About the proffesionals following the groups.

9 “Nitravel” travel agency, Svetozara Markovića 2O, Niš, nitravel@nitravel.rs, www.nitravel.rs; Gordana Stanković, general manager 
In general, Niš recognized this, but we still don't have a clear idea about the possibilities of thematic tours and these must be introduced to all the people working in tourism branch in Niš. Alsto it is necessary to decide which tours are the attractive ones and we should offer them to wider audience. Too many tours can make a mess and as such none of them won't be recognized by tourists. As we said: abandoning the old fashion city tour and to stop offering it is the first step. Also, we must understand that it is better, easier and cost-effective to organize more shorter and themed tours then one longer tour. These tours can satisfy the tourists having more time in Niš: one shorter tour and a lunch, free time, overnight and tomorrow one more short themed tour will leave greater impression on them then a tour where they had to be patient and concentrated for 4 hours. On their vacation!

\section{References}

Dobre, G. (2005). Osnove turizma, teorija i praksa, Visoka škola za turisički menadžment, Šibenik.

Genov, G. redaktor (2008). Turizam posebnih interesa, Selektivni oblici turizma, priručnik, Čigura print, Beograd.

Jovanović, V. (2OI3). Tematski turizam, skripta, prvo izdanje, Univerzitet Singidunum, Beograd.

Jovičić, Ž. (1992). Fenomenologija turizma, Naučna knjiga, Beograd.

Milenković, R. S. (I999). Turistička aktivnost u tržišnoj privredi, DD IP „Vuk Karadžić“, Paraćin. Stefanović, V., Azemović, N. (2OII). Marketing u turizmu, Prirodno-matematički fakultet, Niš.

Štetić, S., Šimičević, D., Ćurčić, N. (2OI3). Specifični oblici turizma, Beograd, $2 \mathrm{OI} 3$. Unković, S., Zečević, B. (2009). Ekonomika turizma, Ekonomski fakultet, Beograd. Veljković, S. (2009). Marketing usluga, Ekonomski fakultet, Beograd. 